\title{
PEMBELAJARAN BERBASIS VIDEO UNTUK MENINGKATKAN PEMAHAMAN KONSEP IPA PESERTA DIDIK DI SD
}

\author{
VIDEO BASED EDUCATION IN IMPROVING CONCEPT \\ UNDERSTANDING OF SCIENCE SUBJECT FOR ELEMENTARY \\ SCHOOL STUDENTS
}

\author{
Ujiati Cahyaningsih*1, Ipang Muhammad Sofyan ${ }^{2}$ \\ ${ }^{1,2}$ Program Studi Pendidikan Guru Sekolah Dasar, Fakultas Keguruan dan Ilmu Pendidikan, \\ Universitas Majalengka, Indonesia, \\ e-mail: *1 ujiati.cahyaningsih@gmail.com, ${ }^{2}$ ipangms0963.im@gmail.com
}

\begin{abstract}
ABSTRAK
Penelitian ini dilatarbelakangi dengan masih rendahnya pemahaman peserta didik pada konsep IPA. Tujuan penelitian ini yaitu untuk meningkatkan pemahaman peserta didik pada konsep IPA melalui penerapan media berbasis video. Penelitian ini merupakan penelitian tindakan kelas yang dilaksanakan di kelas III SDN Cimuncang II. Subjek penelitian adalah peserta didik kelas III yang terdiri dari 24 peserta didik. Teknik pengumpulan data yang digunakan adalah tes, observasi dan dokumentasi. Hasil penelitian menunjukkan bahwa media berbasis video dalam pelajaran IPA dapat meningkatkan pemahaman peserta didik pada konsep IPA. Hal ini ditunjukkan dengan peningkatan nilai yang diperoleh setiap siklus. Nilai rata-rata kelas yang diperoleh peserta didik sebelum pemberian tindakan adalah 62,5 sedangkan persentase peserta didik yang mencapai ketuntasan belajar adalah 37,5\% . Pada siklus I, nilai rata-rata kelas yang diperoleh peserta didik adalah 69,67 sedangkan persentase jumlah peserta didik yang mencapai ketuntasan belajar adalah 62,5\%. Pada siklus II, nilai rata-rata kelas yang diperoleh peserta didik mencapai 81,5 sedangkan persentase jumlah peserta didik yang memperoleh nilai mencapai ketuntasan belajara adalah 87,5\%. Media berbasis video hendaknya dapat dipersiapkan secara seksama, mulai dari persiapan yang maksimal, bervariasi dan menarik, alokasi waktu yang digunakan, sampai strategi pelaksanaan yang tepat.
\end{abstract}

Kata kunci: pemahaman konsep, media berbasis video, IPA

\begin{abstract}
Low understanding founded on students regarding concept of science motivates this study. The aim of this study is to improve students' understanding concept of biology subject through video. This is an experimental research conducted in grade III of SDN Cimuncang II. All 24 students of grade III are the research subjects. Test, observation, and documentation were used as data collection methods. The research result shows that video based education used in biology subject can improve students' understanding concept of biology. This statement is strengthened by raising scores obtained in each cycle. Average score of all grades III before treatment is 62.5 with only $37.5 \%$ of students reach the minimal completeness standards. In cycle I average score reaches is 69.67 with $62.5 \%$ of students reach the minimal completeness standards. In cycle II average score reaches 81.5 with $87.5 \%$ of students reach the minimal completeness standards. Therefore, video as a medium should be prepared carefully, starting from maximal preparation, interesting variations, right time allocation, to good implementation strategy.
\end{abstract}

Keywords: concept understanding, video based medium, science 


\section{PENDAHULUAN}

Media pembelajaran adalah salah satu komponen yang mempunyai peranan penting dalam suatu proses pembelajaran untuk dapat meningkatkan kualitas hasil belajar peserta didik. Media pembelajaran dapat berupa seluruh alat dan bahan yang digunakan dalam kegiatan belajar mengajar, meliputi radio, televisi, buku, koran, majalah dan sebagainya [1]. Dengan demikian, dapat dikatakan bahwa media pembelajaran merupakan segala sesuatu yang dapat digunakan dalam proses pembelajaran yang dapat mendorong terjadinya proses belajar.

Pembelajaran IPA memerlukan pengalaman langsung untuk dapat meningkatkan pemahaman konsep. Kegiatan langsung yang dilaksanakan akan membuat peserta didik belajar secara konkret dari hal-hal nyata disekelilingnya, bukan sekedar teori dari buku pelajaran saja [2]. Pada kenyataannya, pembelajaran IPA lebih sering dilaksanakan di dalam kelas, tanpa melibatkan lingkungan sekitarnya, termasuk alam. Oleh sebab itu, untuk menunjang proses pembelajaran IPA di ruang kelas, perlu diimbangi dengan penggunaan teknologi, untuk dapat meminimalisir kebingungan peserta didik tentang hal-hal abstrak dari konsep IPA yang disampaikan guru.

Wawancara yang telah dilakukan terhadap guru kelas III SDN Cimuncang II, pemanfaatan media dalam pembelajaran IPA hanya berorientasi pada buku pelajaran dan Lembar Kerja Siswa (LKS). Disamping itu, pembelajaran juga masih berpusat pada guru, kurang memberikan kesempatan peserta didik untuk mengembangkan kreativitas dan pemecahan masalah. Pada pelaksanaannya, pembelajaran IPA juga lebih banyak menyampaikan konsepkonsep kepada peserta didik.

Berdasarkan data awal juga diketahui bahwa sebanyak 62,5\% nilainya masih dibawah Kriteria Ketuntasan Minimal (KKM) dan baru 37,5\% peserta didik yang sudah diatas KKM, dari KKM yang telah ditentukan sebesar 70. Oleh karena itu, untuk menunjang keberhasilan dan pemahaman konsep peserta didik dalam proses pembelajaran, guru memerlukan sarana untuk dapat menyampaikan materi dengan baik maupun menarik sehingga dapat dipahami oleh peserta didik.

Media pembelajaran berbasis video adalah salah satu hal yang dapat diterapkan dalam pembelajaran di kelas, khususnya dalam pembelajaran IPA. Berdasarkan hasil wawancara yang telah dilakukan, pada muatan pembelajaran lain, video juga pernah digunakan sebagai media pembelajaran bagi peserta didik di SDN Cimuncang II. Akan tetapi, penggunaan media berbasis video tidak sering dilakukan. Hal ini karena terbatasnya sarana yang ada di sekolah, seperti tidak adanya layar, sehingga sorotan video dibiarkan jatuh ke whiteboard. Terlebih pencahayaan yang masuk keruang kelas terlalu terang, sehingga mengakibatkan penyajian video menjadi kurang jelas.

Video sendiri memiliki berbagai peran, selain sebagai sarana hiburan, video juga dapat berfungsi sebagai media pembelajaran [3]. Media berbasis video akan memperjelas penjelasan yang disampaikan guru, sehingga peserta didik akan lebih mudah memahami dan menerima materi yang disampaikan [4]. Video dapat menampilkan situasi, kejadian, keadaan atau kondisi suatu lingkungan yang berbeda-beda dalam waktu yang relatif singkat. Dengan demikian, video akan memberikan kesempatan kepada peserta didik untuk mendiskusikan hal-hal yang telah disaksikan bersama-sama [5].

Penggunaan video dalam kegiatan pembelajaran tentu harus dipersiapkan dengan baik, dari segi fasilitas, maupun konten materinya, agar semua pesan dapat tersampaikan dengan baik. Media pembelajaran berbasis video termasuk salah satu media yang menerapkan teknologi di era 4.0, sehingga akan dapat mempengaruhi pencapaian pembelajaran [6]. Video akan dapat mengarahkan perhatian peserta didik untuk dapat berkonsentrasi pada materi yang dipelajari sehingga pemahaman konsep peserta didik terhadap materi tersebut akan meningkat. Oleh sebab itu, penelitian ini sangat perlu untuk dilakukan agar dapat mengetahui keefektivan video dalam meningkatkan pemahaman konsep IPA peserta didik Sekolah Dasar. 


\section{METODE PENELITIAN}

Penelitian ini merupakan penelitian tindakan kelas (PTK) yang dilaksanakan di SDN Cimuncang II Kecamatan Malausma, Kabupaten Majalengka. Waktu penilitian adalah semester genap tahun ajaran 2017/2018. Subyek penelitian adalah peserta didik kelas III sebanyak 24 orang yang terdiri dari 14 laki-laki dan 10 perempuan. Teknik pengumpulan data yang digunakan yaitu tes, observasi dan dokumentasi. Tes digunakan untuk mengetahui sejauh mana keberhasilan proses belajar mengajar yang dilakukan pada akhir kegiatan tiap-tiap siklus.

Tes yang digunakan dalam penelitian ini adalah tes belajar yang digunakan untuk mengukur kemampuan pemahaman konsep peserta didik. Observasi dilakukan untuk mengetahui perkembangan kegiatan belajar peserta didik, melalui pengisian lembar observasi peserta didik dan kegiatan mengajar guru pada setiap pertemuan. Observasi terhadap guru difokuskan pada kemampuan guru dalam mengelola kelas serta merangsang keaktifan peserta didik dalam pembelajaran yang sedang berlangsung.

Sementara itu, observasi terhadap peserta didik difokuskan pada kemampuan peserta didik dalam mengikuti pembelajaran IPA melalui penerapan media pembelajaran berbasis video. Dokumentasi ini berupa foto yang dapat digunakan sebagai bukti dari setiap kegiatan yang telah dilakukan dan untuk memperjelas serta menguatkan data dalam penelitian. Teknik analisis data yang digunakan adalah analisis deskriptif kuantitatif untuk menganalisis hasil tes akhir setiap siklus dan analisis deskriptif kualitatif untuk hasil observasi setiap siklus.

\section{HASIL DAN PEMBAHASAN}

\section{Hasil Penelitian}

\section{Pemahaman Konsep Peserta didik Ketika Menggunakan Media Pembelajaran Berbasis Video di SDN Cimuncang II}

Setelah peneliti melaksanakan tindakan pada siklus I dan II, peneliti telah mendapatkan data-data yang diperlukan dalam penelitian tindakan kelas ini. Data-data yang diperoleh meliputi data hasil observasi peserta didik dan hasil tes pemahaman konsep peserta didik ketika menggunakan media pembelajaran berbasis video di SDN Cimuncang II. Berikut merupakan hasil penelitian yang didapatkan peneliti yaitu:

Tabel 1. Peningkatan Hasil Tes Evaluasi Peserta didik

\begin{tabular}{|c|c|c|}
\hline No & Tes Evaluasi & Persentase Peningkatan \\
\hline 1. & Pra Siklus & $37,5 \%$ \\
\hline 2. & Siklus I & $62,5 \%$ \\
\hline 3. & Siklus II & $87,5 \%$ \\
\hline
\end{tabular}

Selanjutnya untuk melihat kegiatan peserta didik pada proses pembelajaran dari siklus I tindakan I dan tindakan II, serta siklus II tindakan I dan tindakan II maka dapat dilihat dalam rekapitulasi peningkatan kegiatan peserta didik sebagai berikut.

Tabel 2. Peningkatan Hasil Observasi Peserta didik

\begin{tabular}{|c|l|c|}
\hline No & \multicolumn{1}{|c|}{ Kegiatan Peserta didik } & Persentase Peningkatan \\
\hline 1 & Siklus I Tindakan I & $62,5 \%$ \\
\hline 2 & Siklus I Tindakan II & $75 \%$ \\
\hline 3 & Siklus II Tindakan I & $79,17 \%$ \\
\hline 4 & Siklus II Tindakan II & $95,83 \%$ \\
\hline
\end{tabular}

Berdasarkan hasil tes evaluasi peserta didik pada siklus I yaitu terdapat 15 orang peserta didik yang tuntas atau $62,5 \%$ dan yang belum tuntas 9 orang peserta didik atau 37,5\%. Sedangkan pada siklus II yaitu 21 orang peserta didik yang tuntas atau $87,5 \%$, dan yang belum tuntas 3 orang 
peserta didik atau $12,5 \%$. Untuk lembar observasi kegiatan peserta didik pada siklus I tindakan I yaitu $62,5 \%$ dan pada tindakan II yaitu $75 \%$. Sedangkan pada siklus II tindakan I yaitu $79,17 \%$ dan pada tindakan II yaitu $95,83 \%$. dari hasil evaluasi di siklus I dan siklus II mengalami peningkatan dan sudah memenuhi kriteria ketuntasan minimal yaitu $75 \%$.

\section{Media Berbasis Video dapat Meningkatkan Pemahaman Konsep Peserta didik}

Penerapan media berbasis video dapat meningkatkan pemahaman konsep peserta didik kelas III SD Negeri Cimuncang II Kecamatan Malausma Kabupaten Majalengka. Hal ini dapat dilihat dari persentase peningkatan nilai rata-rata peserta didik dari pra siklus, siklus I, dan siklus II sebagai berikut:

Peningkatan Nilai Rata-Rata Peserta didik

\begin{tabular}{|c|c|c|}
\hline No & Kegiatan Peserta didik & Rata-Rata Nilai \\
\hline 1 & Pra Siklus & 62,5 \\
\hline 2 & Siklus I & 69,67 \\
\hline 3 & Siklus II & 81,5 \\
\hline
\end{tabular}

Pada pra siklus, nilai rata-rata yang diperoleh peserta didik hanya 62,5, meningkat menjadi 69,67 pada siklus I, kemudian pada siklus II mengalami peningkatan secara signifikan yaitu 81,5. Jumlah peserta didik mampu mencapai KKM lebih dari 75\% pada siklus I ada 15 peserta didik, dan pada siklus II ada 21 peserta didik. Persentase ketuntasan pada siklus I sebesar 62,5\%, dan pada siklus II sebesar $87,5 \%$. Dari data-data tersebut dapat diketahui bahwa pembelajaran IPA khususnya pada materi lingkungan melalui penerapan media berbasis video dapat meningkatkan pemahaman konsep peserta didik pada pembelajaran IPA kelas III SD Negeri Cimuncang II Kecamatan Malausma Kabupaten Majalengka.

\section{Pembahasan}

Media Pembelajaran Berbasis Video dalam Memahamkan Konsep IPA Pada Peserta didik

Berdasarkan hasil tes evaluasi peserta didik pada siklus I yaitu terdapat 15 orang peserta didik yang tuntas atau $62,5 \%$ dan yang belum tuntas 9 orang peserta didik atau $37,5 \%$. Sedangkan pada siklus II yaitu 21 orang peserta didik yang tuntas atau $87,5 \%$, dan yang belum tuntas 3 orang peserta didik atau $12,5 \%$. Untuk lembar observasi kegiatan peserta didik pada siklus I tindakan I yaitu $62,5 \%$ dan pada tindakan II yaitu $75 \%$. Sedangkan pada siklus II tindakan I yaitu $79,17 \%$ dan pada tindakan II yaitu 95,83\%. dari hasil evaluasi di siklus I dan siklus II mengalami peningkatan dan sudah memenuhi kriteria ketuntasan minimal yaitu $75 \%$.

Peserta didik dikatakan telah memahami konsep yang disajikan dapat dilihat dari kriteria ketuntasan yang diperoleh secara klasikal. Pembelajaran dikatakan berhasil, jika peserta didik yang telah tuntas KKM minimal sebanyak 75\% dari keseluruhan peserta didik yang ada [7]. Oleh sebab itu, dapat disimpulkan bahwa penerapan media berbasis video dapat memahamkan konsep IPA, khususnya materi lingkungan di kelas III SD Negeri Cimuncang II Kecamatan Malausma, Kabupaten Majalengka.

Media pada dasarnya sebagai perantara untuk dapat menyampaikan suatu informasi. Media pembelajaran berbasis video akan membantu guru dalam menyampaikan informasi kepada peserta didik. Video juga telah terbukti layak dan efektif digunakan dalam proses pembelajaran [8]. Hal ini karena, video merupakan serangkaian gambar hidup yang menyajikan informasi, sehingga dapat memahamkan suatu konsep kepada penontonnya [9]. Dengan demikian, media berbasis video dapat memahamkan peserta didik terkait materi yang disampaikan.

Perpaduan gambar dan suara dalam video menjadikan pesan yang hendak tersampaikan lebih jelas. Media berbasis video juga berguna membantu guru dalam menjelaskan materi yang bersifat praktik karena akan lebih mudah dimengerti peserta didik [10]. Materi dalam IPA tentu bukan hanya sekedar teori, akan tetapi juga ada hal-hal yang perlu dipraktikkan. Media berbasis 
video tentu sangat mendukung pelaksanaan pembelajaran IPA, karena membuat peserta didik lebih mengerti terkait dengan materi yang disampaikan.

Media pembelajaran berbasis video selain membuat peserta didik lebih mengerti materi juga membuat peserta didik tidak kebingungan akan hal-hal yang hendak dilakukan. Hasil penelitian menunjukkan, ada pengaruh yang signifikan penggunaan media pembelajaran berbasis video terhadap aktivitas belajar peserta didik [11]. Peningkatan aktivitas belajar tentu akan membuat peserta didik secara tidak langsung mempelajari isi materi, sehingga dapat membuat peserta didik paham akan hal yang disampaikan.

\section{Media Berbasis Video dapat Meningkatkan Pemahaman Konsep IPA Pada Peserta didik}

Pada pra siklus, nilai rata-rata yang diperoleh peserta didik hanya 62,5 , meningkat menjadi 69,67 pada siklus I, kemudian pada siklus II mengalami peningkatan secara signifikan yaitu 81,5. Jumlah peserta didik mampu mencapai KKM lebih dari $75 \%$ pada siklus I ada 15 peserta didik, dan pada siklus II ada 21 peserta didik. Persentase ketuntasan pada siklus I sebesar $62,5 \%$, dan pada siklus II sebesar $87,5 \%$. Dari data-data tersebut dapat diketahui bahwa pembelajaran IPA khususnya pada materi lingkungan melalui penerapan media berbasis video dapat meningkatkan pemahaman konsep peserta didik pada pembelajaran IPA kelas III SD Negeri Cimuncang II Kecamatan Malausma Kabupaten Majalengka.

Peningkatan pemahaman konsep IPA pada peserta didik setelah diterapkan media pembelajaran berbasis video selaras dengan penelitian terdahulu yang pernah dilakukan. Hasil penelitian terdahulu menunjukkan hasil belajar meningkat setelah diterapkan media pembelajaran berbasis video, yang diperkuat dengan hasil uji hipotesis yang telah dilakukan, disimpulkan bahwa video berpengaruh cukup besar terhadap hasil belajar peserta didik [12]. Meningkatnya hasil belajar ini tentu menunjukkan bahwa pemahaman peserta didik terhadap konsep IPA telah meningkat.

Penelitian lain juga menunjukkan hasil serupa bahwa, hasil belajar peserta didik meningkat setelah diterapkan media pembelajaran berbasis video yang dilihat dari ketuntasan belajar setiap siklus yang meningkat dari 34,7\% menjadi 86,95\% [13]. Meningkatnya ketuntasan belajar ini tentu dibarengi dengan meningkatnya pemahaman peserta didik terhadap konsep IPA.

Penggunaan video dalam kegiatan belajar mengajar tentu berdampak positif bagi peserta didik. Video pembelajaran akan mempermudah guru dalam mendemonstrasikan materi, memotivasi peserta didik, memberikan tutorial, serta mengefektifkan waktu [14]. Selain itu, sajian yang menarik dan memanjakan mata, tentu membuat peserta didik lebih mudah dalam memahami materi. Hal-hal inilah yang membuat penggunaan video dapat meningkatkan pemahaman peserta didik pada konsep IPA.

\section{SIMPULAN}

Dari hasil kegiatan pembelajaran yang telah dilakukan selama dua siklus dan berdasarkan seluruh pembahasan serta analisis yang telah dilakukan maka peneliti mangambil kesimpulan bahwa, "Pembelajaran dengan menggunakan media Berbasis Video dapat meningkatkan pemahaman konsep peserta didik, yang ditandai dengan ketuntasan hasil tes formatif peserta didik tiap siklus. Sebelumnya pada pra siklus sebesar 37,5\% kemudian terjadi peningkatan pada siklus I yaitu $66,67 \%$, kemudian meningkat kembali pada siklus II yaitu $87,5 \%$. Penerapan media pembelajaran berbasis video dapat meningkatkan pemahaman konsep peserta didik pada pembelajaran IPA di kelas III SDN Cimuncang II Kecamatan Malausma Kabupaten Majalengka Tahun Pelajaran 2017/2018.

Ada beberapa saran yang peneliti kemukakan, semoga dapat menjadi masukan guna meningkatkan kemampuan pemahaman konsep peserta didik agar lebih baik lagi. Adapun saran yang ingin peneliti sampaikan yaitu: 1) Kepada guru kelas diharapkan untuk lebih memotivasi peserta didik dengan menciptakan pembelajaran yang kreatif, inovatif dan menyenangkan yang 
dapat menimbulkan ransangan kepada peserta didik untuk belajar, yang salah satunya dapat menggunakan media berbasis video yang disesuaikan dengan materi ajar dan disesuaikan dengan tingkat perkembangan anak. Agar penggunaan media berbasis video dapat berhasil dengan baik, hendaknya dipersiapkan secara seksama, mulai dari persiapan yang maksimal, bervariasi dan menarik, alokasi waktu yang digunakan, sampai strategi pelaksanaan yang tepat;

2) Kepada pihak sekolah agar lebih memperhatikan pengadaan media maupun saranaprasana penunjang kegiatan belajar mengajar, agar pembelajaran dapat berlangsung dengan baik, efektif, dan efisien; 3) Kepada pihak lembaga, untuk menciptakan suasana pembelajaran yang kondusif dan berkualitas, hendaknya mulai diperhatikan dari saat ini terutama bagi para pemegang keputusan, agar lebih banyak memperhatikan sebuah lembaga pendidikan, terutama pendidikan sekolah dasar yang secara geografis berada di daerah pelosok; 4) Kepada peneliti selanjutnya yang ingin mengkaji lebih jauh tentang permasalahan yang sama dengan peneliti ini, hendaknya lebih cermat dan mengupayakan pengkajian teori-teori secara lebih mendalam lagi yang berkaitan dengan penggunaan media berbasis video, guna melengkapi kekurangan yang ada agar diperoleh hasil yang lebih baik.

\section{DAFTAR PUSTAKA}

[1] W. Sanjaya, "Media Komunikasi Pembelajaran," Kencana Prenada Media Group. p. 278, 2012.

[2] N. Sumarni, R. W. Astuti, and S. D. Mumpuni, "Keterampilan Hidroponik Untuk Perkembangan Sosial-Emosional Siswa Sekolah Dasar," Jurnal Ilmiah KONTEKSTUAL, vol. 2, no. 01, pp. 22-29, 2020, [Online]. Available: http://jurnal.umus.ac.id/index.php/kontekstual/article/view/245.

[3] M. Fadhli, "Pengembangan Media Pembelajaran Berbasis Video Kelas IV Sekolah Dasar," Jurnal Dimensi Pendidikan dan Pembelajaran, vol. 3, no. 1, pp. 24-29, 2015, [Online]. Available: http://journal.umpo.ac.id/index.php/dimensi/article/view/157.

[4] F. S. Wahid, M. A. Purnomo, and S. M. Ulya, "Analisis Peran Guru Dalam Pemanfaatan Lingkungan Sekolah Terhadap Kreativitas Belajar Siswa," Jurnal Ilmiah KONTEKSTUAL, vol. 2, no. 01, pp. 38-42, 2020, [Online]. Available: http://jurnal.umus.ac.id/index.php/kontekstual/article/view/247.

[5] F. Hutapea and N. A. Purba, "Pengaruh Penggunaan Media Pembelajaran Berbasis Video Terhadap Hasil Belajar Mengait Pada Siswa Tata Busana Smk Negeri 8 Medan," Jurnal Pendidikan Teknologi Dan Kejuruan, vol. 17, no. 1, pp. 58-66, 2017, [Online]. Available: https://jurnal.unimed.ac.id/2012/index.php/mbt/article/view/4814.

[6] D. R. Triputra et al., "Implementasi Media Pembelajaran Vlog Materi," Jurnal Ilmiah KONTEKSTUAL, vol. 1, no. 01, pp. 18-25, 2019, [Online]. Available: http://jurnal.umus.ac.id/index.php/kontekstual/article/view/54.

[7] E Mulyasa, "Pengembangan dan Implementasi kurikulum 2013," Bandung: Remaja Rosadakarya. 2017.

[8] B. A. I. Williyana, Y. N. Kholisho, and A. Fathoni, "Pengembangan Media Pembelajaran Berbasis Video Tutorial Interaktif Pada Mata Pelajaran Teknik Animasi 2 Dimensi," EDUMATIC: Jurnal Pendidikan Informatika, vol. 2, no. 2, pp. 52-58, 2018, [Online]. Available: http://e-journal.hamzanwadi.ac.id/index.php/edumatic/article/view/869.

[9] A. Y. Utomo and D. Ratnawati, "Pengembangan Video Tutorial Dalam Pembelajaran Sistem Pengapian Di Smk," Taman Vokasi, vol. 6, no. 1, p. 68, 2018, [Online]. Available: https://jurnal.ustjogja.ac.id/index.php/tamanvokasi/article/view/2839.

[10] D. Safitri and H. I. Syofii, "Pengembangan Media Pembelajaran Berbasis Video Animasi Pada Mata Pelajaran Mekanika Teknik," Jurnal PendidikanTeknik Mesin, vol. 6, no. 1, pp. 1-7, 2019, [Online]. Available: https://ejournal.unsri.ac.id/index.php/ptm/article/view/6967/4026.

[11] S. Anshor, I. G. Sugiyanta, and R. K. S. U, "Penggunaan Media Pembelajaran Berbasis 
Video Terhadap Aktivitas Dan Hasil Belajar Geografi," Jurnal Penelitian Geografi, vol. 3 , no. 7, pp. 1-9, 2015, [Online]. Available: http://jurnal.fkip.unila.ac.id/index.php/JPG/article/view/10376.

[12] A. Busyaeri, T. Udin, and A. Zaenudin, "Pengaruh Penggunaan Video Pembelajaran Terhadap Peningkatan Hasil Belajar Mapel IPA Di MIN Kroya Cirebon," Al Ibtida: Jurnal Pendidikan Guru MI, vol. 3, no. 1, pp. 116-137, 2016, [Online]. Available: https://www.syekhnurjati.ac.id/jurnal/index.php/ibtida/article/view/584.

[13] M. Miftahussurur and P. Pramono, "Peningkatkan Hasil Belajar Menggunakan Media Video Pembelajaran Pada Kompetensi Dasar Memelihara/Servis Sistem Pendingin Mesin," Jurnal Pendidikan Teknik Mesin Unnes, vol. 16, no. 1, pp. 31-36, 2016, [Online]. Available: https://journal.unnes.ac.id/nju/index.php/JPTM/article/view/9153.

[14] K. Agustini and J. G. Ngarti, "Pengembangan Video Pembelajaran Untuk Meningkatkan Motivasi Belajar Siswa Menggunakan Model R \& D," Jurnal Ilmiah Pendidikan dan Pembelajaran, vol. 4, no. 1, pp. 62-78, 2020, [Online]. Available: https://ejournal.undiksha.ac.id/index.php/JIPP/article/download/18403/14752. 